\title{
Monitoring ectomycorrhizal fungi at large scales for science, forest management, fungal conservation and environmental policy
}

\author{
Laura M. Suz • Nadia Barsoum • Sue Benham • Chris Cheffings • Filipa Cox • \\ Louise Hackett • Alan G. Jones • Gregory M. Mueller • David Orme • Walter Seidling • \\ Sietse Van Der Linde • Martin I. Bidartondo
}

Received: 30 June 2014 / Accepted: 12 December 2014 / Published online: 22 January 2015

(C) INRA and Springer-Verlag France 2015. This article is published with open access at Springerlink.com

\begin{abstract}
- Key message The ICP Forests network can be a platform for large-scale mycorrhizal studies. Mapping and monitoring of mycorrhizas have untapped potential to inform science, management, conservation and policy regarding distributions, diversity hotspots, dominance and rarity, and indicators of forest changes.
\end{abstract}

\section{Handling Editor: Ana RINCON}

Contribution of the co-authors All co-authors attended the workshop in which this article is based and contributed to the generation of ideas and their discussion. MI Bidartondo and LM Suz led the writing, helped by essential comments and contributions of all co-authors.

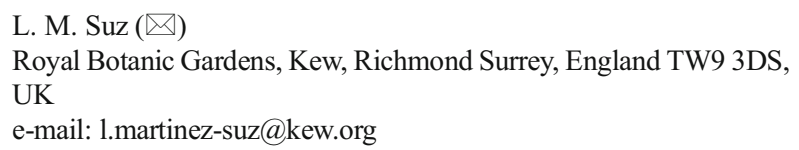

F. Cox

School of Earth, Atmospheric and Environmental Sciences, University of Manchester, Manchester M13 9PL, UK

e-mail: filipa.cox@manchester.ac.uk

\section{Hackett}

Woodland Trust, Kempton Way, Grantham NG31 6LL, UK

e-mail: LouiseHackett@woodlandtrust.org.uk
- Context A dearth of information about fungi at large scales has severely constrained scientific, forest management, fungal conservation and environmental policy efforts worldwide. Nonetheless, fungi fulfil critical functional roles in our changing environments and represent a considerable proportion of terrestrial biodiversity. Mycorrhizal fungi are increasingly viewed as a major functional guild across forest

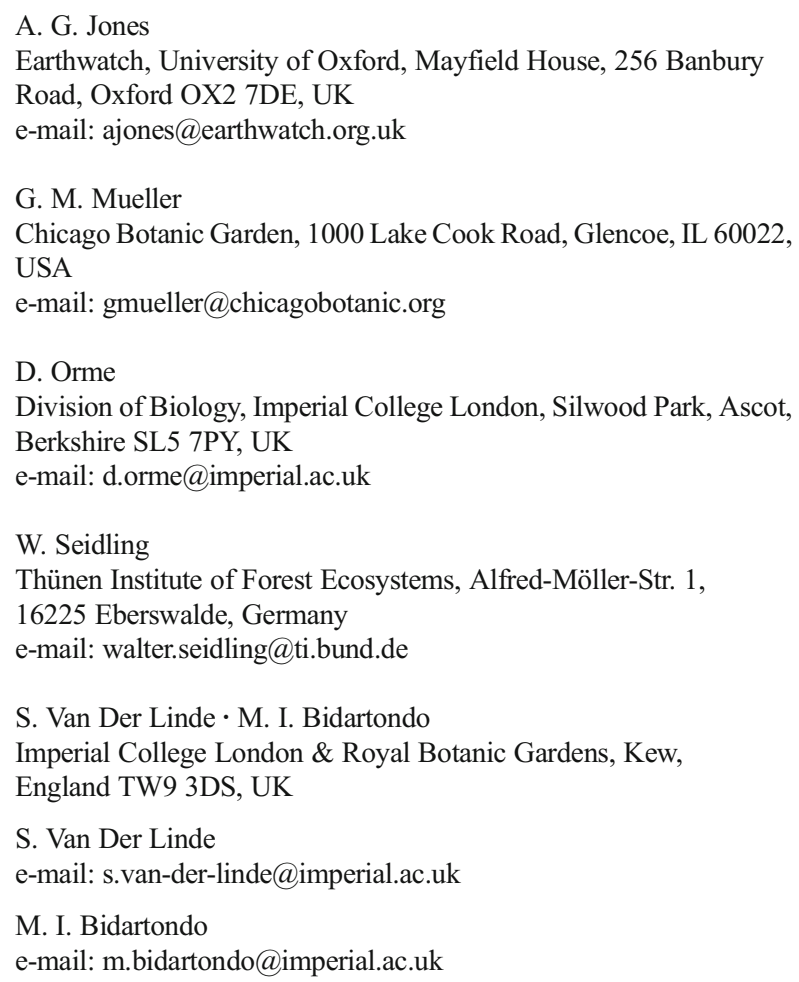


ecosystems, and our ability to study them is expanding rapidly.

- Aims This study aimed to discuss the potential for starting a mycorrhizal monitoring programme built upon the existing forest monitoring network, raise questions, propose hypotheses and stimulate further discussion.

- Results An overview of the state-of-the-art regarding forest ectomycorrhizal ecology raises questions and recommendations for scaling up mycorrhizal assessments aimed at informing a variety of stakeholders, with a new focus on conservation and policy.

- Conclusion Fungal research and conservation are areas that can be informed by ICP Forests and may lead to useful spinoffs; research linked to long-term forest monitoring plots will enhance the relevance of science and conservation.

\section{Keywords Mycorrhizas · ICP Forests · Monitoring · Air} pollution $\cdot$ Indicator $\cdot$ Red list

\section{Introduction}

Nearly all tree roots in boreal and temperate forests form ectomycorrhizas. These intimate fungus-plant mutualisms play crucial ecological roles by determining the nutrient acquisition and drought tolerance of trees (Smith and Read 2008). There is concern that we lack baseline data on mycorrhizal species distributions and abundances against which to assess the effects of global change (Courty et al. 2010; Kjøller et al. 2012; Lilleskov and Parrent 2007; Peay et al. 2010). Research on mycorrhizas has been focused at local scales (i.e. stand level), leaving a widely recognised gap in our understanding of patterns of diversity and their drivers at landscape, regional, continental and global scales (Bruns 1995; Peay et al. 2010). We still know very little about diversity and its drivers for any key soil organisms above local scales, even though various ecological processes are only apparent at much larger spatial scales (Levin 2000). For ectomycorrhizal (ECM) fungi, mapping, monitoring and evaluation need to reach beyond national boundaries to reflect large-scale fungal distributions and their drivers of change.

The vast European forest monitoring network (www.icpforests.org) is an ideal study platform because its intensively monitored long-term forest plots have tremendous potential for developing and scaling up forest mycorrhizal research and biomonitoring (Cox 2010; Cox et al. 2010a, b; Suz et al. 2014). In April 2014, a multidisciplinary workshop focused on how the network can be used to investigate mycorrhizal diversity and ecology at large scales (www3.imperial.ac.uk/ ecosystemsandenvironment/events/workshops/ nercimpactworkshops/macroecologyofmicrobes). Presentations and discussions assessed the state-of-the-art, findings from ECM communities in a pine study across England and Germany (Cox et al. 2010b), a study of oak plots across Europe (Suz et al. 2014) and from an ongoing Europe-wide analysis of ECM fungi in spruce, pine and beech plots carried out in plots belonging to this network and using its rich in situ environmental data (listed below). The complementary needs and resources of the monitoring, nature conservation, scientific and forest management communities were discussed. A new focus was generating data on ECM communities to inform fungal conservation in the context of the recent International Union for the Conservation of Nature Initiative on Global Fungal Red Listing (Dahlberg and Mueller 2011, iucn.ekoo.se). Participants included government and NGO forest managers, government and academic conservation experts and ecologists. The outcomes of discussions and the questions raised are summarised here. The overarching goals of this article are to stimulate debate, to encourage expanding the spatial and temporal scales across which studies are carried out and to explain the rationale behind the ongoing assessments of mycorrhizas across Europe's forest monitoring network.

Overall, five main questions covering current knowledge gaps were formulated: (1) What are the spatial patterns of mycorrhizal diversity and community structure? (2) What are the environmental and ecological factors that control mycorrhizal distributions at landscape and larger scales? (3) What are the likely responses of dominant mycorrhizal fungi to global change and how will they affect the long-term spatial cohesion of communities? (4) Will communities change (e.g. shifts in dominant species and/or extinction of certain fungi) under changing environmental conditions, and if so, will these changes affect forest growth and resilience to global change? (5) How can forests be managed more sensitively to protect and enhance the diversity and functions of fungi?

Progress in answering some of these questions is being made by combining molecular ecology with geographic information systems (e.g. Tse-Laurence and Bidartondo 2011) to generate new data on ECM communities through sampling forest plots belonging to the ICP Forests network. These approaches reduce previous analytical limitations in large-scale mycorrhizal studies. Engaging stakeholders, such as forest managers, conservationists and policy makers, is essential to raise awareness, enhance collaborations and join fundraising efforts to include mycorrhizal surveys in forest monitoring.

\section{How to assess fungal distributions}

The distinctive life cycles and growth forms of fungi (see Peay et al. 2008 for an excellent review) pose unique challenges and opportunities for mapping fungal species distributions at large spatial and temporal scales. At present, the limited, typically national, data available on fungal species distributions and 
how they change originate from studying the reproductive structures visible to the naked eye that are formed by some macroscopic fungi (e.g. mushrooms, truffles, crusts) (Arnolds 1991; Kauserud et al. 2012). Most of the more apparent mushrooms (and to a lesser extent the more cryptic truffles and crusts) are ephemeral (days to weeks) and sporadically produced but have been recorded for over a century and are well researched. Some fruiting bodies can be assessed in the field via multi-year surveys. Reproductive structures are partially represented in collections at museums for the purposes of taxonomic research, some of which have been databased and can be accessed via the public Global Biodiversity Information Facility (www.gbif.org).

In addition to visible fruiting bodies, there are fungal structures such as filaments (mycelium), dispersal propagules (spores and sclerotia) and structures formed together with plant host roots - called mycorrhizas - that are all found in the soil. These structures may not be visible to the naked eye but can be much larger and/or longer-lived than reproductive structures - e.g. the average size of individuals of the ECM fungus Suillus variegatus has been reported to range from 10 to $20 \mathrm{~m}$ (Dahlberg 1997) and sclerotia of the ubiquitous ECM fungus Cenococcum geophilum might rest in soil for over 1, 000 years (Watanabe et al. 2007). Less well recorded and researched than fruiting bodies are the soil filaments that are also ephemeral (days to weeks) and the spores that are potentially viable for years (Nguyen et al. 2012). Soil filaments can be assessed through in-growth mesh bags or cores, and resistant spores and sclerotia can be assessed via soil bioassays. Spores and sclerotia of some ECM fungi can be abundant in soil, forming spore banks analogous to the seed banks of plants. This variety of forms merits thorough consideration when designing field sampling and interpreting data.

Despite the relatively short life (weeks) of the individual ECM roots, the diversity of ECM fungi can remain stable at scales $>10 \mathrm{~cm}$ (Cox 2010; Douhan et al. 2011; Izzo et al. 2005; Koide et al. 2007; Lian et al. 2006). Crucially, ectomycorrhizas are always present as nearly all roots are colonised by mycorrhizal fungi - even under high nutrient availability — as shown by a meta-analysis (Cudlin et al. 2007). Sampling roots is thus a convenient and efficient way to monitor active ECM populations likely to give a more complete characterisation of the mycorrhizal communities present compared to spore, mycelium and fruiting body surveys. Functional traits of particular interest in ectomycorrhizas are conferred by their soil exploration types which are characterised by short, medium or long filaments linking mycorrhizal roots to soil (Agerer 2001, 2006) and their ability to uptake organic nitrogen $(\mathrm{N})$ (driven by the production and release into soil of a battery of fungal enzymes, some of which may degrade recalcitrant organic matter as a side effect, Bödeker et al. 2014). Moreover, these functional traits that define each exploration type can confer different capabilities with regard to storing carbon and taking up and translocating nutrients (Courty et al. 2010; Hobbie and Agerer 2010). We have seen that mycorrhizal communities in temperate oak forests respond differently to environmental variables depending on their soil exploration type (Suz et al. 2014). Because the effects of changes in the presence and proportions of different ECM functional groups across Europe may affect the resilience of forests to environmental change, they need more investigation. However, trait databases for mycorrhizas are in their infancy (e.g. www.deemy.de) with only about 320 mycorrhizal types characterized, although information on soil exploration strategies of $143 \mathrm{ECM}$ genera has been recently compiled (Tedersoo and Smith 2013).

As with other organisms, the main public information repository for fungi as DNA sequence data is the International Nucleotide Sequence Database (www.insdc.org), though some specialised public sub-databases are also available-e.g. UNITE for the fungal DNA barcode for identification (unite. ut.ee) and MarjaAM for arbuscular mycorrhizal fungi (maarjam.botany.ut.ee) - . These DNA databases effectively integrate data from all fungal structures and life history stages. Globally, it is estimated that most fungal species, particularly those outside the developed world, await taxonomic description and are not yet represented in collections or databases (Blackwell 2011). Of the fungi that have a taxonomic description, relatively few have been sequenced (Brock et al. 2009). Some of these 'unknown' fungi-undescribed and/or unsequenced — can be dominant belowground even in relatively well-studied European forests (e.g. Cox et al. 2010b).

\section{Monitoring mycorrhizas for improved forest management}

Since mycorrhizal communities are integral to most forest ecosystems and play essential roles - accessing different inorganic and organic nutrient pools, conferring drought tolerance or plant resistance to pathogens - there is a need to better understand how they vary among forest types, across environmental gradients and management regimes in order to practice more sensitive management (e.g. thinning, clearing, fire control, harvest regulation of edible mushrooms). There is evidence, for example, that tree species composition influences mycorrhizal communities (Ishida et al. 2007) and that there are generalist and host-specific fungi (e.g. Molina et al. 1992). Where 'non-native' mycorrhizas are imported on planted trees, especially on non-native tree species (Pennington et al. 2011), what are the implications on existing mycorrhizal communities, particularly in any neighbouring native tree species stands? There are examples of invasive ECM fungi-see Vellinga et al. (2009) for a review on ECM introductions - such as the deadly European Amanita phalloides in North America (Wolfe et al. 2010). Moreover, what are the consequences of a much altered mycorrhizal 
community? What is the link between major changes in forest condition (e.g. dieback) and the structure of mycorrhizal communities? It is intriguing that strong correlations have recently been reported between eucalyptus forest decline, soil chemistry and ECM community structure (Horton et al. 2013).

There is also a gap in understanding how much the success of forest restoration and afforestation is linked to restoring and building mycorrhizal communities. For instance, is it necessary to restore the mycorrhizal community of a native broadleaf woodland when converting from conifer to broadleaf or vice versa? Baskin (1997) describes a number of cases where highly disturbed forest soils no longer support the mycorrhizal communities required for the successful establishment of saplings, resulting in many failed reforestation attempts. The protection, restoration and creation of woodland both near and far from existing woodlands as well as conifer-broadleaf transitions are of interest to many land managers - how do mycorrhizas drive or constrain these different practices? How redundant are roles played by different ECM fungi in a forest? Under which conditions those roles might become unique and susceptible to disappearing? Many woodlands are heavily fragmented, e.g. $74 \%$ of English woodland is ca. $100 \mathrm{~m}$ from a woodland edge (Riutta et al. 2014). Edge effects on light, water and pollution are relatively well understood, but woodland edges typically represent strong mycorrhizal transitions as well and these have only received limited attention (e.g. Branco et al. 2013).

\section{The present and future of global fungal conservation}

The very limited existing fungal diversity and distribution data (e.g. Fig. 1) are a critical gap in nature conservation; many fungi are now known to have discrete distributions, similar to those of animals and plants, but distribution and population trend data for fungi lag far behind equivalent datasets available for plants and animals. For detailed reviews of different aspects of the importance of fungal conservation, see Pringle et al. (2011) and others in the same issue of Fungal Ecology. Historically, there has been some resistance to red listing from within the fungal research community, largely due to a lack of basic ecological information about species. Consequently, fungi have long been overlooked by and left out of the influential International Union for the Conservation of Nature (IUCN) process of listing rare and endangered species to enhance their protection (i.e. currently only one macrofungus and two lichenised fungi are among the over 21,000 red-listed organisms). This is particularly striking when we consider the important functional role of many fungi in ecosystems and also the vast scale at which wild ECM forest fungi are commercially harvested and exported (Sitta and Davoli 2012).

Undoubtedly, more diversity data are needed - especially at large spatial and temporal scales - but it is already possible to identify targets and risk factors and to quantify uncertainty, at least locally, nationally or regionally (Dahlberg and Mueller 2011; Lilleskov et al. 2011; Molina et al. 2011). A consistent

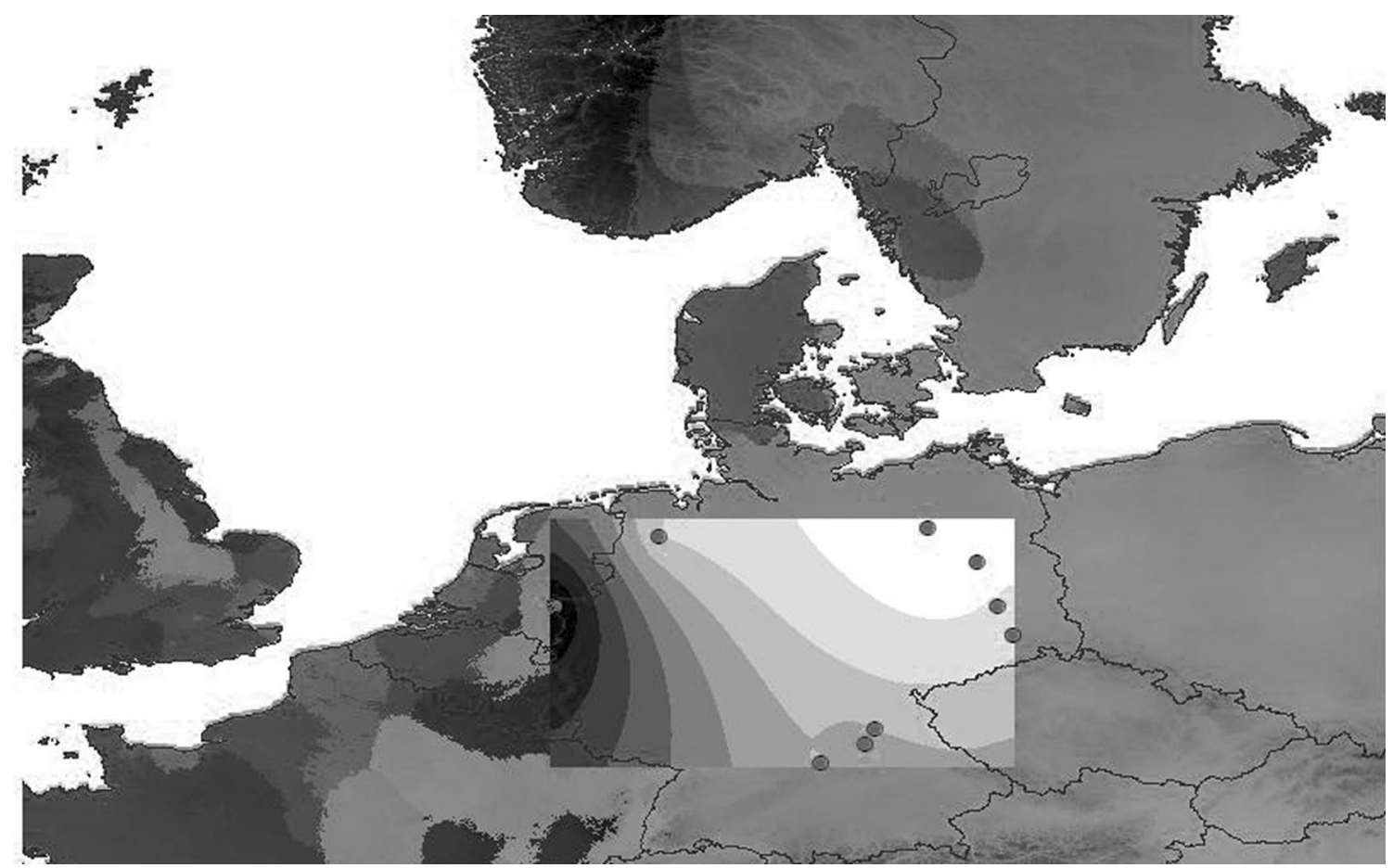

Fig. 1 A first geographic distribution map for the false truffle Elaphomyces granulatus - a dominant mycorrhizal fungus of pine forests overlooked in fruiting body surveys due to its underground fruiting that is currently a candidate for global red listing-generated using inverse distance-weighted interpolation on DNA sequences from Level II pine sites and georeferenced GenBank accessions showing that large-scale mapping of dominant ectomycorrhizal fungi is feasible 
problem for red listing of any particular species is how to scale up or extrapolate ecology and distribution information that justifies the need for conservation of fungi at risk beyond local, national or regional datasets, e.g. from relatively wellstudied Nordic, Dutch or Swiss fungi, to nearby countries, pan-European scales and beyond. Generation time and persistence are key considerations when assessing changes in population size over time. Assessments following IUCN guidelines are based on three generations. A key question for fungal conservation remains developing biologically meaningful, defensible estimations of generation times for species of ECM fungi. The suggested generation times presented in Dahlberg and Mueller (2011) need additional validation from a diversity of species across disturbance gradients, soil differences and host associations. Belowground sampling coupled with population genetic studies of targeted taxa/habitats can provide these needed data. How long do fungi persist belowground under particular environmental pressures (e.g. pollution)? What is the host range of obligate symbiotic fungi? Thanks to research developments - largely driven by the molecular ecology revolution since the 1990smany of these questions have been answered at local scales and that has now finally been sufficient to attract interest and support from IUCN, but extrapolation is risk-laden. The current first IUCN Red Listing Initiative for Fungi can ultimately lead to identifying endangered fungi, indicators of restoration success (e.g. UK waxcap grasslands) and fungal diversity hotspots or key fungal biodiversity areas. Better integration between the research and conservation communities is urgently needed. The biomonitoring community can act as a natural integrator with its platform for generating rigorous data on mycorrhizal diversity, distribution, turnover (spatially and temporally), host specificity, and responses to anthropogenic stressors and land management issues that are key needs of the fungal conservation community. These data are starting to be captured through the first mycorrhizal sampling of diverse ICP Forests plots. Ongoing communication between the conservation, research and biomonitoring communities and tentative statistical modelling approaches will help ensure sharing of data and ideas and also enable action on the ground in terms of potential funding and site availability for research.

\section{Ectomycorrhizas and conservation policy}

Ongoing barcoding of sporocarps initiatives, population genetic studies and regional collections database projects are providing the comparative data needed to integrate roots and other environmental samples to enable us to understand multiple aspects of biodiversity (taxonomic, ecological and genetic) across various scales in ways never before possible. Issues of scale and evidence quality are of paramount importance for informing policy makers on conservation issues, particularly if costly interventions, such as industry regulation, are required in order to achieve conservation objectives. For instance, consideration of $\mathrm{N}$ deposition impacts needs to be based on both small-scale experimental manipulations and large-scale correlations between biodiversity change and deposition gradients (see Stevens et al. 2011; Emmett et al. 2011; ROTAP 2012). Once small-scale manipulations are combined with greater certainty that large-scale biodiversity change is being driven by $\mathrm{N}$ deposition, then it becomes possible to modify the critical value used in mapping and to start to infer pressures and threats on protected sites (Whitfield et al. 2012). Agencies such as the UK Joint Nature Conservation Committee support national fungal red listing (i.e. Boletaceae, Geastraceae), but they are also increasingly focused on acquiring information about fungal communities in the context of a range of ecosystem processes (for instance how $\mathrm{N}$ deposition will affect ecosystem function via impacts on fungal communities), rather than only on rare and/or declining species. Clear demonstrations of changes in mycorrhizal communities with increasing $\mathrm{N}$ deposition analogous to the changes that have been reported for other organisms (Stevens et al. 2011; Emmett et al. 2011) are emerging from analyses of ICP Forests mycorrhizal data (Cox et al. 2010b; Suz et al. 2014). There are also some hints as to which traits are likely to respond, e.g. soil exploration strategy. This leads to the question of how fungi recover through spore banks and/ or via dispersal? And, when mycorrhizal community recovery is relatively slow, how does it limit vascular plant recovery?

\section{Why monitor mycorrhizas in the ICP Forest Network Level II plots?}

The ICP Forest Level II plots have been used successfully for national (e.g. Helmisaari et al. 2009) and increasingly for trans-national (e.g. Clarke et al. 2011; Cox et al. 2010b; Kristensen et al. 2004) research. European forests are uniquely suitable and tractable for the study of mycorrhizas because (1) there is relatively low forest biodiversity compared to North America and Asia, (2) an extensive and intensive forest monitoring network is available, (3) over $95 \%$ of forest area is covered by ECM trees, (4) fungi are relatively wellcharacterised compared with other areas of the world and (5) there are strong natural and anthropogenic environmental gradients (e.g. pollution, Taylor et al. 2000). Thus, it is an excellent place to generate understanding and predictions on the behaviour of the natural environment and its resources by developing and testing bioindicators, contributing to assessments of carbon sequestration, macronutrient cycling, and identifying biotic and abiotic cause-effect relationships responsible for biome condition. There are about 800 intensively monitored (Level II) plots, 0.25 ha each, covering Europe's major forest types. Monitoring in Level II plots includes (1) 
continuous measurement of atmospheric deposition, soil solution chemistry and meteorology; (2) biannual measurement of foliar chemistry (i.e. C, $\mathrm{Ca}, \mathrm{Cd}, \mathrm{Cu}, \mathrm{Fe}, \mathrm{K}, \mathrm{Mg}, \mathrm{Mn}, \mathrm{N}, \mathrm{P}$, $\mathrm{Pb}, \mathrm{S}, \mathrm{Zn}$ ); (3) annual measurement of crown condition; (4) recording of tree growth and understory vegetation every 5 years; and (5) decadal measurements of solid phase parameters (most recently 2006-2007). Soil solution chemistry parameters include organic $\mathrm{C}$, total $\mathrm{N}$, carbonates, exchangeable acidity, exchangeable cations, $\mathrm{Al}, \mathrm{Ca}, \mathrm{Cd}, \mathrm{Cr}, \mathrm{Cu}, \mathrm{Fe}, \mathrm{Hg}, \mathrm{K}$, $\mathrm{Mg}, \mathrm{Mn}, \mathrm{Na}, \mathrm{P}, \mathrm{Pb}, \mathrm{S}, \mathrm{Zn}$ and total elements. Physical soil structure is characterised using organic layer weight, percentage of coarse fragments, bulk density, particle size distributions, clay, silt and sand content. At selected plots, additional information is gathered continuously on stand structure (including the amount of dead wood), lichen diversity, ambient air quality, phenology and/or litterfall. Growing season temperature and meteorological measurements are available from many plots. Land history is available from the national or regional agencies that are responsible for managing the plots. Monitoring in ICP Forests is discussed in detail by Ferretti and Fischer (2013).

Mycorrhizas are increasingly recognised as a major 'missing' biotic factor regulating development, biodiversity and productivity in terrestrial ecosystems (Peay et al. 2010). The ICP Forests network represents an unrivalled platform for research to fill this knowledge gap (Cox et al. 2010a). A first essential research step is to produce a large dataset for robust tests of key macroecological hypotheses and to provide the baseline high-quality mycorrhizal data to enable future monitoring of changes in community composition and diversity. Among them: (1) increased $\mathrm{N}$ availability impacts Europe's mycorrhizal diversity; (2) soil $\mathrm{pH}$, altitude, stand age and climatic conditions affect mycorrhizas; (3) there are dominant mycorrhizal fungi associated with Europe's major trees; (4) there are geographic 'hotspots' of mycorrhizal biodiversity that correspond with those of vascular plants; (5) mycorrhizal richness follows latitudinal trends; and (6) there are mycorrhizal fungi that can act as indicators of environmental conditions.

A second step should involve multiple scale manipulative experiments across a range of sites in order to maximise predictive power. However, this second future step cannot be designed without the information arising from a baseline assessment of diversity and a macroecological understanding of that diversity across geographic gradients. Furthermore, the effects of experiments may differ from those resulting from long-term geographic gradients, so that both approaches are valuable and complementary.

\section{Large-scale monitoring of mycorrhizas}

So far, mycorrhizal assessments as part of the network (Fig. 2) have been carried out in 12 Scots pine (Pinus sylvestris) ICP
Forest Level II plots in Britain and Germany (Cox et al. 2010b) and 22 oak level II plots (Quercus robur and/or Quercus petraea) across nine countries (Suz et al. 2014). Over 3,000 soil cores have been examined and over 10,000 mycorrhizas analysed using DNA-based techniques that identified 112 mycorrhizal fungi in pine and ca. 400 in oak forests (see Fig. 3a for species accumulation curves). A further study of over 100 spruce, pine and beech plots is due for completion in 2016. The genetic screening approach used allows for the study of long-term associations, provides a least biased sample of the dominant active ECM fungi and preserves mycorrhizal root specimens for further study. Direct observation of fruiting bodies, inoculum potential bioassays to assess spore banks and detection of soil filaments may provide useful complementary information.

Overall, $\mathrm{N}$ pollution and soil $\mathrm{pH}$ are emerging as major factors driving ECM communities through impacts on tree roots, fungi and soil conditions (Fig. 3b). Both mycorrhizal richness and evenness decrease when soil $\mathrm{pH}$ decreases, leading to dominance by acidophilic fungi. Similarly, $\mathrm{N}$ deposition decreases the richness and evenness of mycorrhizal communities, and it shifts dominance towards nitrophilic fungi resulting in a decrease or even loss of $\mathrm{N}$-sensitive fungi. There are species that show a consistently negative response to increasing $\mathrm{N}$ inputs and are not detected in plots receiving high $\mathrm{N}$ loads. There is a need to detect the critical $\mathrm{N}$ loads for mycorrhizal communities in European forests above which communities suffer changes that can affect forest ecosystem processes, as previously reported for forests in North America (Pardo et al. 2011) and oak forests in Europe (Bobbink and Hettelingh 2011; Suz et al. 2014). These thresholds may be similar to other taxa such as vascular plants that also demonstrate a sensitive response to $\mathrm{N}$ loading and changes in soil $\mathrm{pH}$ (Ikauniece et al. 2013). Simultaneously, we need to identify species and sets of species that can indicate and predict ecosystem condition and vice versa (e.g. Suz et al. 2014).

So far, we have found that (1) nitrogen is a primary determinant of mycorrhizal distribution in Europe (Cox et al. 2010b; Suz et al. 2014; Fig. 3b); (2) rarely studied, poorly culturable and/or inconspicuously fruiting mycorrhizal fungi can dominate belowground both within and across plots (e.g. the truffles Elaphomyces and Hydnotrya and the crusts Piloderma and Tomentella), some of which (e.g. Elaphomyces muricatus and Hydnotrya tulasnei) are being considered for red listing by IUCN based on fruiting body records; (c) in common with other large perennial organisms, ECM communities can be spatially stable between seasons and years, even following seedling transplant between environmentally divergent plots (Cox 2010); (d) there can be abundant dormant propagules (i.e. sclerotia) in soil from fungi found rarely as mycorrhizas, questioning the assumption that bulk soil environmental DNA is from active fungi (e.g. Anderson et al. 2014; Talbot et al. 2014); and (e) dominant 

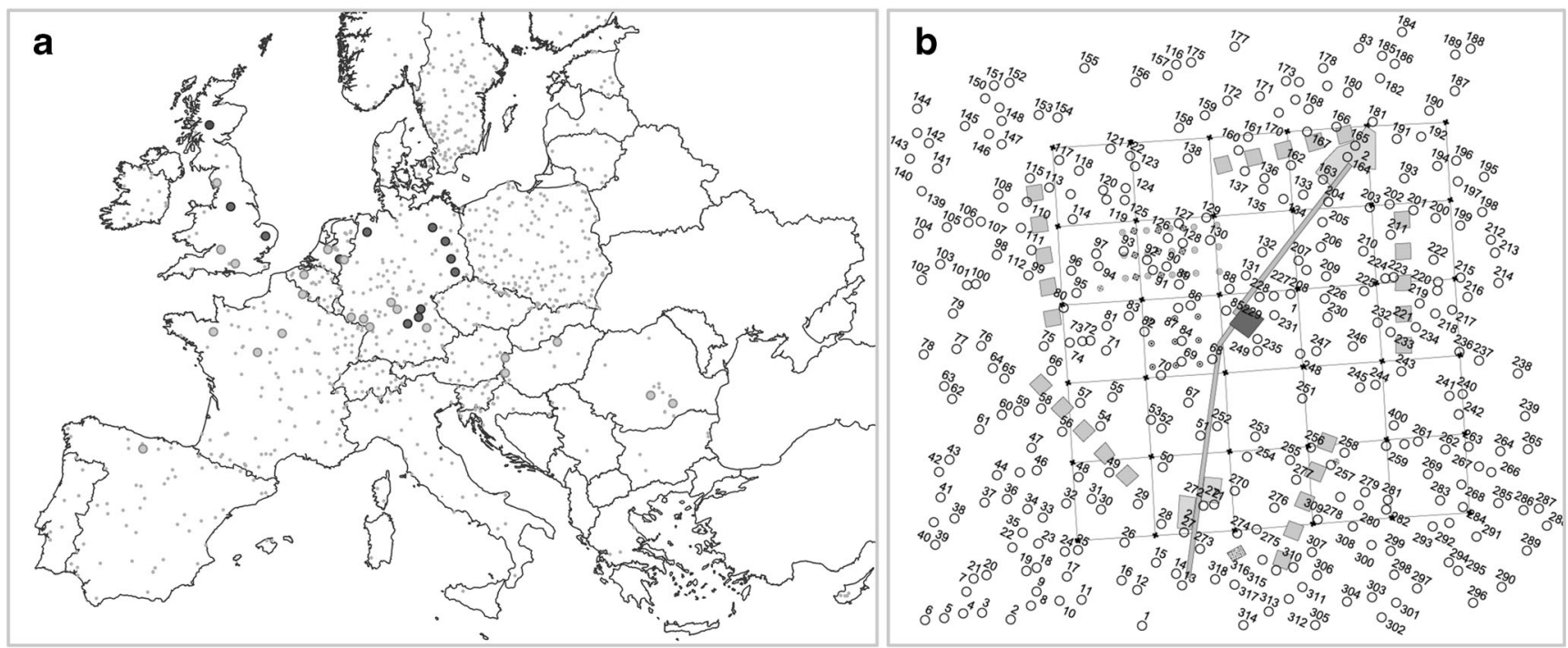

Fig. 2 a Thirty-four Level II plots belonging to the ICP Forests network have been used so far for mycorrhizal assessments. Dark grey circles are Scots pine plots sampled by Cox et al. (2010b), and light grey circles are oak plots sampled by Suz et al. (2014). b A schematic map of a typical
Level II plot shows the presence of numbered trees that facilitates randomisation of tree to tree transects for mycorrhizal root sampling within plots, as well as allowing the spatial location of samples to be recorded should within-site spatial analyses or re-sampling be required but taxonomically unknown ECM fungi can be linked to previously informally described mycorrhizas (e.g. a Leotiomycete to 'Piceirhiza sulfo-incrustata' sensu Palfner et al. 2005).

\section{Conclusion}

The availability of long-term datasets is the strongest limiting factor in global change research (Willis and MacDonald 2011). Soil biology data will be of value to forest monitoring efforts that can impact on policy by UNECE and the EU (e.g. Biodiversity Strategy). European trees and ground floor vegetation are being monitored and are leading to significant findings (e.g. Dirnboeck et al. 2014; Seidling et al. 2008; Van Dobben and de Vries 2010; Veresoglou et al. 2014), but fungi are not yet included in the current monitoring scheme. Science and conservation are areas that can be built into ICP Forests and/or may lead to useful spin-offs; research linked to these long-term plots has the potential to enhance the relevance of science and conservation.

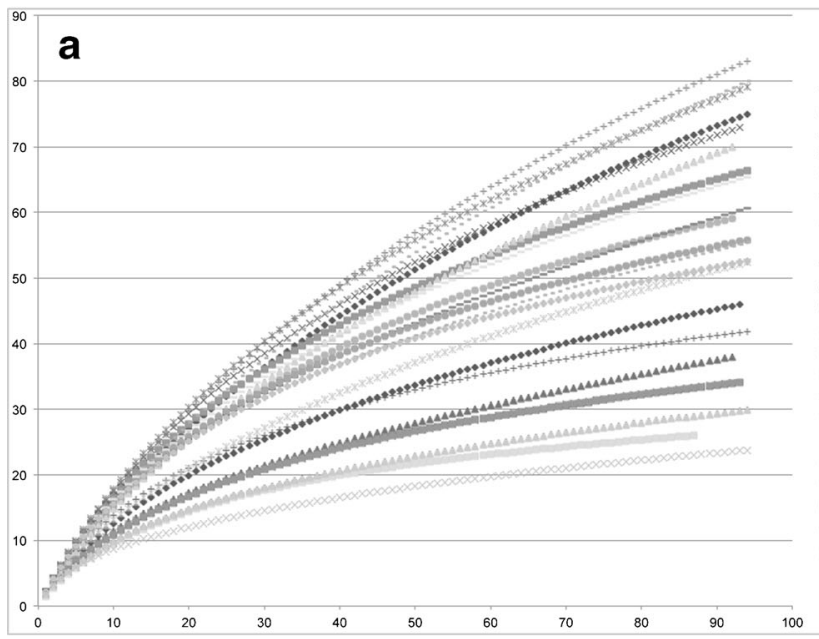

Fig. 3 A Species accumulation curves (Mao Tau) showing that the sampling design used recovered on average $70 \%$ of the estimated richness across plots ( $x$-axis: number of soil cores sampled for mycorrhizas; $y$-axis: number of fungal taxa detected). b Non-metric

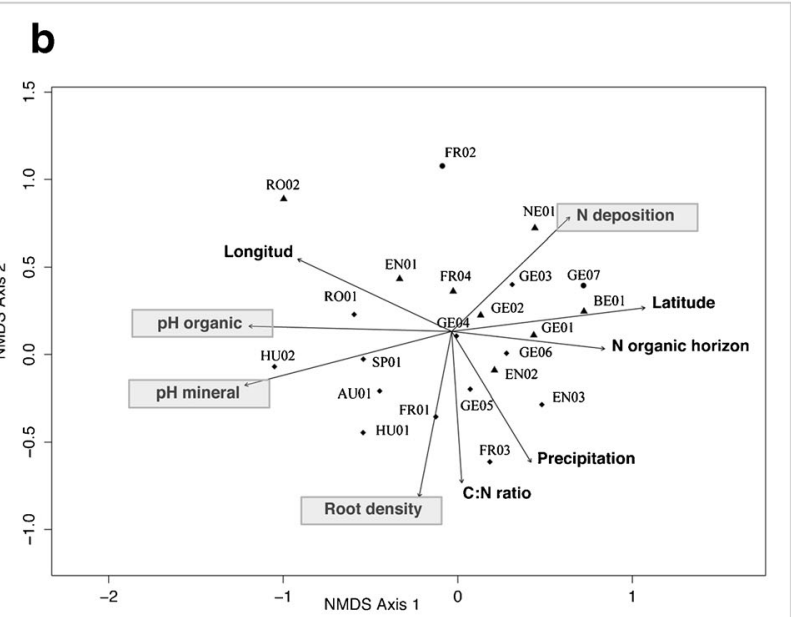

multidimensional scaling (NMDS) analysis of mycorrhizal communities at oak Level II plots shows that among other variables, nitrogen availability, soil $\mathrm{pH}$ and root density are main drivers of mycorrhizal diversity and community composition (Suz et al. 2014) 
Acknowledgments The ideas presented in this article were discussed and developed at a workshop supported by the UK Natural Environment Research Council, Imperial College London's Grand Challenges in Ecosystems and the Environment initiative and the Royal Botanic Gardens, Kew. Research projects were supported by a Marie Curie postdoctoral fellowship to LMS (FP7-PEOPLE-2009-IEF-253036), to two BenthamMoxon Trust grants to MIB and LMS a NERC case studentship to FC (NER/S/A/2006/14012) and a NERC grant to MIB and DO (NE/ K006339). We are grateful to the constructive comments of two anonymous reviewers.

Open Access This article is distributed under the terms of the Creative Commons Attribution License which permits any use, distribution, and reproduction in any medium, provided the original author(s) and the source are credited.

\section{References}

Agerer R (2001) Exploration types of ectomycorrhizae - a proposal to classify ectomycorrhizal mycelial systems according to their patterns of differentiation and putative ecological importance. Mycorrhiza 11:107-114. doi:10.1007/s005720100108

Agerer R (2006) Fungal relationships and structural identity of their ectomycorrhizae. Mycol Prog 5:67-107. doi:10.1007/s11557-0060505-x

Anderson IC, Genney DR, Alexander IJ (2014) Fine scale diversity and distribution of ectomycorrhizal fungal mycelium in a Scots pine forest. New Phytol 201:423-1430. doi:10.1111/nph.12637

Arnolds E (1991) Decline of ectomycorrhizal fungi in Europe. Agric Ecosyst Environ 35:209-244. doi:10.1016/0167-8809(91)90052-y

Baskin Y (1997) The work of nature: how the diversity of life sustains us. Island Press, Washington, pp 116-117

Blackwell M (2011) The fungi: 1, 2, 3 . . 5.1 million species? Am J Bot 98:426-438. doi:10.3732/ajb.1000298

Bobbink R, Hettelingh JP (2011) Effects of nitrogen deposition on woodland, forest and other wooded land (EUNIS class G). In: Review and revision of empirical critical loads and dose-response relationships. RIVM Report 680359002, pp 135-171

Bödeker IT, Clemmensen KE, de Boer W, Martin F, Olson A, Lindahl BD (2014) Ectomycorrhizal Cortinarius species participate in enzymatic oxidation of humus in northern forest ecosystems. New Phytol 203:245-56. doi:10.1111/nph.12791

Branco S, Bruns TD, Singleton I (2013) Fungi at a small scale: spatial zonation of fungal assemblages around single trees. PLoS ONE 8: e78295. doi:10.1371/journal.pone.0078295

Brock PM, Döring H, Bidartondo MI (2009) How to know unknown fungi: the role of a herbarium. New Phytol 181:719-724. doi:10. 1111/j.1469-8137.2008.02703.x

Bruns TD (1995) Thoughts of the processes that maintain local species diversity of ectomycorrhizal fungi. Plant Soil 170:63-73. doi:10. 1007/BF02183055

Clarke N, Fischer R, de Vries W, Lundin L, Papale D, Vesala T, Merilä P, Matteucci G, Mirtl M, Simpson D, Paoletti E (2011) Availability, accessibility, quality and comparability of monitoring data for European forests for use in air pollution and climate change science. iForest 4:162-166. doi:10.3832/ifor0582-004

Courty PE, Buée M, Diedhiou AG, Frey-Klett P, Le Tacon F, Rineau F, Turpault P, Uroz S, Garbaye J (2010) The role of ectomycorrhizal communities in forest ecosystem processes: new perspectives and emerging concepts. Soil Biol Biochem 42:679-698. doi:10.1016/j. soilbio.2009.12.006

Cox F (2010) The mycorrhizas of Europe's pine forests in the context of nitrogen pollution. $\mathrm{PhD}$ thesis, Imperial College London, UK
Cox F, Barsoum N, Bidartondo MI, Borja I, Lilleskov E, Nilsson LO, Rautio P, Tubby K, Vesterdal L (2010a) A leap forward in geographic scale for forest ectomycorrhizal fungi. Ann For Sci 67:200. doi:10.1051/forest/2009107

Cox F, Barsoum N, Lilleskov EA, Bidartondo MI (2010b) Nitrogen availability is a primary determinant of conifer mycorrhizas across complex environmental gradients. Ecol Lett 13:1103-1113. doi:10. 1111/j.1461-0248.2010.01494.x

Cudlin P, Kieliszewska-Rojucka B, Rudawska M, Grebenc T, Alberton O, Lehto T, Bakker MR, Børja I, Konôpka B, Leski T, Kraigher H, Kuyper TW (2007) Fine roots and ectomycorrhizas as indicators of environmental change. Plant Biosyst 141:406-425. doi:10.1080/ 11263500701626028

Dahlberg A (1997) Population ecology of Suillus variegatus in old Swedish Scots pine forests. Mycol Res 101:47-54. doi:10.1017/ S0953756296002110

Dahlberg A, Mueller GM (2011) Applying IUCN red-listing criteria for assessing and reporting on the conservation status of fungal species. Fungal Ecol 4:147-162. doi:10.1016/j.funeco.2010.11.001

Dirnboeck T, Grandin U, Bernhardt-Roemermann M et al (2014) Forest floor vegetation response to nitrogen deposition in Europe. Glob Chang Biol 20:429-440. doi:10.1111/gcb.12440

Douhan GW, Vincenot L, Gryta H, Selosse M-A (2011) Population genetics of ectomycorrhizal fungi: from current knowledge to emerging directions. Fungal Biol 115:569-597. doi:10.1016/j. funbio.2011.03.005

Emmett BA, Rowe EC, Stevens CJ, Gowing DJ, Henrys PA, Maskell LC, Smart SM (2011) Interpretation of evidence of nitrogen impacts on vegetation in relation to UK. JNCC Report 449. Peterborough, UK. http://jncc.defra.gov.uk/page-5895

Ferretti M, Fischer R (2013) Forest monitoring. Methods for terrestrial investigations in Europe with an overview of North America and Asia. Developments in environmental science. Krupa, S.V. (Ed.). Elsevier.

Helmisaari H-S, Ostonen I, Lohmus K, Derome J, Lindroos AJ, Merilä P, Nöjd P (2009) Ectomycorrhizal root tips in relation to site and stand characteristics in Norway spruce and Scots pine stands in boreal forests. Tree Physiol 29:445-456. doi:10.1093/treephys/tpn042

Hobbie EA, Agerer R (2010) Nitrogen isotopes in ectomycorrhizal sporocarps correspond to belowground exploration types. Plant Soil 327:71-83. doi:10.1007/s11104-009-0032-z

Horton BM, Glen M, Davidson NJ, Ratkowsky D, Close DC, Wardlaw TJ, Mohammed C (2013) Temperate eucalypt forest decline is linked to altered ectomycorrhizal communities mediated by soil chemistry. For Ecol Manag 302:329-337. doi:10.1016/j.foreco. 2013.04.006

Ikauniece S, Brumelis G, Kasparinskis R, Nikodermus O, Straupe I, Zarinš J (2013) Effect of soil and canopy factors on vegetation of Quercus robur woodland in the boreo-nemoral zone: a plant-trait based approach. For Ecol Manag 295:43-50. doi:10.1016/j.foreco. 2013.01.019

Ishida TA, Nara K, Hogetsu T (2007) Host effects on ectomycorrhizal fungal communities: insight from eight host species in mixed conifer-broadleaf forests. New Phytol 174:430-440. doi:10.1111/j. 1469-8137.2007.02016.x

Izzo A, Agbowo J, Bruns TD (2005) Detection of plot-level changes in ectomycorrhizal communities across years in an old-growth mixedconifer forest. New Phytol 166:619-630. doi:10.1111/j.1469-8137. 2005.01354.x

Kauserud H, Heegaard E, Buentgen U, Halvorsen R, Egli S, Senn-Irlet B, Krisai-Greilhuber I, Daemon W, Sparks T, Norden J, Hoiland K, Kirk P, Semenov M, Boddy L, Stenseth NC (2012) Warminginduced shift in European mushroom fruiting phenology. Proc Natl Acad Sci U S A 109:14488-14493. doi:10.1073/pnas.1200789109

Kjøller R, Nilsson L-O, Hansen K, Schmidt IK, Vesterdal L, Gundersen P (2012) Dramatic changes in ectomycorrhizal community 
composition, root tip abundance and mycelial production along a stand-scale nitrogen deposition gradient. New Phytol 194:278-286. doi:10.1111/j.1469-8137.2011.04041.x

Koide RT, Shumway DL, Xu B, Sharda JN (2007) On temporal partitioning of a community of ectomycorrhizal fungi. New Phytol 174:420-429. doi:10.1111/j.1469-8137.2007.02000.x

Kristensen HL, Gundersen P, Callesen I, Reinds GJ (2004) Throughfall nitrogen deposition has different impacts on soil solution nitrate concentration in European coniferous and deciduous forests. Ecosystems 7:180-92. doi:10.1007/s10021-003-0216-y

Levin SA (2000) Multiple scales and the maintenance of biodiversity. Ecosystems 3:498-506. doi:10.1007/s100210000044

Lian C, Narimatsu M, Nara K, Hogetsu T (2006) Tricholoma matsutake in a natural Pinus densiflora forest: correspondence between aboveand below-ground genets, association with multiple host trees and alteration of existing ectomycorrhizal communities. New Phytol 171:825-836. doi:10.1111/j.1469-8137.2006.01801.x

Lilleskov EA, Parrent JL (2007) Can we develop general predictive models of mycorrhizal fungal community-environment relationships? New Phytol 174:250-256. doi:10.1111/j.1469-8137.2007.02023.x

Lilleskov EA, Hobbie EA, Horton TR (2011) Conservation of ectomycorrhizal fungi: exploring the linkages between functional and taxonomic responses to anthropogenic $\mathrm{N}$ deposition. Fungal Ecol 4:174-183. doi:10.1016/j.funeco.2010.09.008

Molina R, Massicotte M, Trappe JM (1992) Specificity phenomena in mycorrhizal symbioses: community-ecological consequences and practical implications. In: Allen MF (ed) Mycorrhizal functioning: an integrative plant-fungal process. Chapman and Hall, NY, pp 357-423

Molina R, Horton TR, Trappe JM, Marcot BG (2011) Addressing uncertainty: how to conserve and manage rare or little-known fungi. Fungal Ecol 4:134-146. doi:10.1016/j.funeco.2010.06.003

Nguyen NH, Hynson NA, Bruns TD (2012) Stayin' alive: survival of mycorrhizal fungal propagules from 6-yr-old forest soil. Fungal Ecol 5:741-746. doi:10.1016/j.funeco.2012.05.006

Palfner G, Casanova-Katny MA, Read DJ (2005) The mycorrhizal community in a forest chronosequence of Sitka spruce Picea sitchensis (Bong.) Carr. in Northern England. Mycorrhiza 15:571-579. doi:10. 1007/s00572-005-0364-3

Pardo LH, Fenn ME, Goodale CL, Geiser LH, Driscoll CT, Aller EB, Baron JS, Bobbink R, Bowman WD, Clark CM, Emmett B, Gilliam FS, Greaver TL, Hall SJ, Lilleskov EA, Liu L, Lynch JA, Nadelhoffer KJ, Perakis SS, Robin-Abbott R, Stoddard JL, Weathers KC, Dennis RL (2011) Effects of nitrogen deposition and empirical nitrogen critical loads for ecoregions of the United States. Ecol Appl 21:3049-3082. doi:10.1890/10-2341.1

Peay KG, Kennedy PG, Bruns TD (2008) Fungal community ecology: a hybrid beast with a molecular master. Bioscience 58:799-810. doi: 10.1641/B580907

Peay KG, Bidartondo MI, Arnolds AE (2010) Not every fungus is everywhere: scaling to the biogeography of fungal-plant interactions across roots, shoots and ecosystems. New Phytol 185:878-882. doi: 10.1111/j.1469-8137.2009.03158.x

Pennington HG, Bidartondo MI, Barsoum N (2011) A few exotic mycorrhizal fungi dominate eucalypts planted in England. Fungal Ecol 4:299-302. doi:10.1016/j.funeco.2011.03.002

Pringle A, Barron E, Sartor K, Wares J (2011) Fungi and the anthropocene: biodiversity discovery in an epoch of loss. Fungal Ecol 4:121-123. doi:10.1016/j.funeco.2011.01.001

Riutta T, Slade EM, Morecroft MD, Bebber DP, Malhi Y (2014) Living on the edge: quantifying the structure of a fragmented forest landscape in England. Landsc Ecol 29:949-961. doi:10.1007/s10980-014-0025-Z

ROTAP (2012) Review of transboundary air pollution, acidification, eutrophication, ground level ozone and heavy metals in the UK. Defra. http://www.rotap.ceh.ac.uk
Seidling W, Fischer R, Granke O (2008) Relationships between forest floor vegetation on ICP Forests monitoring plots in Europe and basic variables in soil and nitrogen deposition. Int J Environ Stud 65:311322. doi:10.1080/00207230701862538

Sitta N, Davoli P (2012) Edible ectomycorrhizal mushrooms: current knowledge and future prospects. In: Zambonelli A, Bonita GM (eds) Soil biology 34. Springer, Berlin, pp 355-380

Smith SE, Read DE (2008) Mycorrhizal symbiosis, 3rd edn. Academic, London

Stevens CJ, Smart SM, Henrys PA, Maskell LC, Walker KJ, Preston CD, Crowe A, Rowe, EC, Gowing DJ, Emmett BA (2011) Collation of evidence of nitrogen impacts on vegetation in relation to UK biodiversity objectives. JNCC Report, No. 447

Suz LM, Barsoum N, Benham S, Dietrich HP, Fetzer KD, Fischer R, García P, Gehrman J, Kristöfel F, Manninger M, Neagu S, Nicolas M, Oldenburger J, Raspe S, Sánchez G, Schröck HW, Schubert A, Verheyen K, Verstraeten A, Bidartondo MI (2014) Environmental drivers of ectomycorrhizal communities in Europe's temperate oak forests. Mol Ecol 23:56285644. doi:10.1111/mec.12947

Talbot JM, Bruns TD, Taylor JW, Bruns TD, Taylor JW, Smith DP, Branco S, Glassman SI, Erlandson S, Vilgalys R, Liao H-L, Smith ME, Peay KG (2014) Endemism and functional convergence across the North American soil mycobiome. Proc Natl Acad Sci U S A 111: 6341-6346. doi:10.1073/pnas.1402584111

Taylor AFS, Martin F, Read DJ (2000) Fungal diversity in ectomycorrhizal communities of Norway spruce (Picea abies (L.) Karst.) and beech (Fagus sylvatica L.) along north-south transects in Europe. Ecol Stud 142:343-365. doi:10.1007/978-3-642-57219716

Tedersoo L, Smith ME (2013) Lineages of ectomycorrhizal fungi revisited: foraging strategies and novel lineages revealed by sequences from belowground. Fungal Biol Rev 27:83-99. doi:10. 1016/j.fbr.2013.09.001

Tse-Laurence MA, Bidartondo MI (2011) Mapping fungi from below ground: online genetic resources and ectomycorrhizal geographic distributions. iForest-Biogeosciences and Forestry 4:252-255. doi: 10.3832/ifor0599-008

Van Dobben H, de Vries W (2010) Relation between forest vegetation, atmospheric deposition and site conditions at regional and European scales. Environ Pollut 158:921-933. doi:10.1016/j.envpol.2009.09.015

Vellinga EC, Wolfe BE, Pringle A (2009) Global patterns of ectomycorrhizal introductions. New Phytol 181:960-973. doi:10. 1111/j.1469-8137.2008.02728.x

Veresoglou SD, Peñuelas J, Fischer R, Rautio P, Sardans J, Merilä P, Tabakovic-Tosic M, Rillig MC (2014) Exploring continental-scale stand health-N:P ratio relationships for European forests. New Phytol 202:422-430. doi:10.1111/nph.12665

Watanabe M, Sato H, Matsuzaki H, Kobayashi T, Sakagami N, Maejima Y, Ohta H, Fujitake N, Hiradate S (2007) C-14 ages and delta C-13 of sclerotium grains found in forest soils. Soil Sci Plant Nutr 53: 125-131. doi:10.1111/j.1747-0765.2007.00121.x

Whitfield C, Hettelingh J-P, Hall J (2012) Critical loads based nitrogen deposition assessment for habitats directive article 17 reporting. JNCC. http://jncc.defra.gov.uk/page-1426

Willis KJ, MacDonald GM (2011) Long-term ecological records and their relevance to climate change predictions for a warmer world. Annu Rev Ecol Evol Syst 42:267-287. doi:10. 1146/annurev-ecolsys-102209-144704

Wolfe BE, Richard F, Cross HB, Pringle A (2010) Distribution and abundance of the introduced ectomycorrhizal fungus Amanita phalloides in North America. New Phytol 185:803-816. doi:10. 1111/j.1469-8137.2009.03097.x 